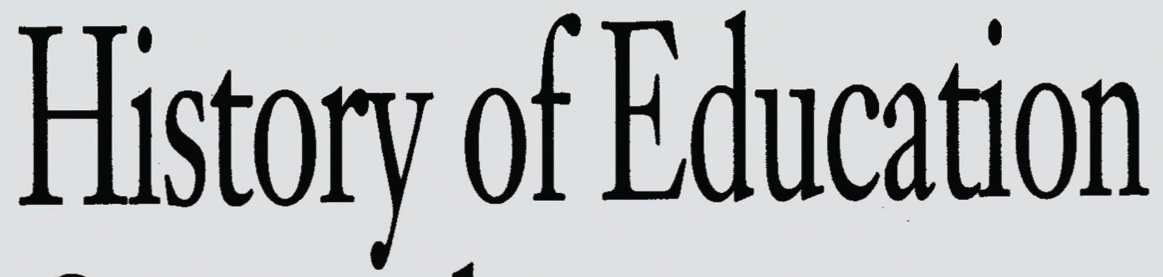

Quarterl

\title{
Winter 2006
}

Volume 46, Number 4 
THE CLAUDE A. EGGERTSEN DISSERTATION PRIZE: This annual \$1000 prize will be awarded for the most outstanding dissertation in the History of Education Quarterly completed in the previous year.

Inquiries should be directed to Kim Tolley, Chair, Eggertsen Dissertation Prize, Department of Advanced Studies, School of Education and Leadership, Notre Dame de Namur University, 1500 Ralston Avenue, Belmont, CA 94002. E-mail: ktolley@ndnu.edu.

THE HISTORY OF EDUCATION SOCIETY AWARD: This award of $\$ 500$ will be made biennially to the best essay in the history of education published in any journal over the previous two years. The next award will be presented at the fall 2006 meeting of the History of Education Society. Any article published in 2004 or 2005 will be eligible for the award.

THE HENRY BARNARD PRIZE: This prize of $\$ 500$ is awarded biennially to the best essay in the history of education by a graduate student. The next award will be presented at the fall 2007 meeting of the History of Education Society. The recipient will have the essay published in the History of Education Quarterly.

Inquiries regarding these two awards should be directed to the chairperson of the Prize Committee: Prof. Jim Carl, Cleveland State University, 2121 Euclid Ave. RT 1444, Cleveland, OH 44115-2214.

OUTSTANDING BOOK AWARD: This award of $\$ 500$ is made annually to the author of the best book on the history of education published in the previous year. The committee will accept nominations but will also make every effort to review all relevant works, whether or not they have been nominated. The award for books bearing 2005 publication dates will be announced at the annual meeting of the Society in 2006.

Inquiries regarding the Outstanding Book Award should be directed to the chairperson: Professor Julie Reuben, Harvard Graduate School of Education, Gutman 421, Cambridge, MA 02138. E-mail: julie_reuben@harvard.edu.

The Society reserves the right not to make awards in those years when the Prize Committee judges all entries to be of insufficient quality. 
History of Education Quarterly

University of Illinois at Urbana-Champaign

360 Education Building, MC-708

1310 South Sixth Street, Champaign, IL 61820

Phone: 217 333-2446 (Office), Fax: 217 244-7064

http://www.ed.uiuc.edu/hes/INDEX.htm

\section{Senior Editor \\ James D. Anderson, University of Illinois at Urbana-Champaign}

Yoon K. Pak,

University of Illinois at Urbana-Champaign

\section{Co-Editors}

Christopher M. Span, University of Illinois at Urbana-Champaign
Barbara Beatty, Wellesley College

Michael Fultz, University of

Wisconsin, Madison

\section{Associate Editors}

Robert A. Levin, TeacbFirst, Inc.

Linda Perkins, Claremont Graduate Scbool

Eileen Tamura, University of Hawaii

\section{Sharon S. Lee}

\section{Editorial Assistants}

Evelyn A. Perez

Mario R. Perez

\section{Editorial Board}

Helena Ribeiro De Castro, University of Lisbon Ruben Donato, University of Colorado, Boulder Mona Gleason, University of British Columbia Joyce Goodman, University of Winchester Ian Grosvenor, University of Birmingbam Philo Hutcheson, Georgia State University W. Bruce Leslie, State University of New York, Brockport

Kriste Lindenmeyer, University of Maryland Baltimore County

Amy Thompson McCandless, College of Cbarleston
Gary McCulloch, University of London Siobhan Moroney, Lake Forest College Robert Osgood, Indiana University Purdue University Adah Ward Randolph, Obio University Jon Reyhner, Nortbern Arizona University Alan Sadovnik, Rutgers Unversity Kim Tolley, Notre Dame de Namur University Cally Waite, Teachers College, Columbia University Joseph Watras, University of Dayton Clive Whitehead, University of Western Australia William Wraga, University of Georgia

The History of Education Society is an international scholarly society. Its purposes are to encourage and facilitate research in the history of education; to promote and improve the teaching of history of education; to encourage cooperation among specialists in history of education; and to promote an appreciation of the value of historical perspective in the making of educational policy. The Society is affiliated with the International Standing Conference for the History of Education, and members of the Society are automatically members of the Standing Conference.

\author{
President \\ Kate Rousmaniere, Miami (Obio) \\ University (2006)
}

David Labaree, Stanford University, Past President (2005)

Jana Nidiffer, Univensity of Micbigan (2004-2006)
Vice-President

Nancy Beadie, University of

Washington (2006)
Secretary-Treasurer

Robert Hampel, University of

Delaware (2006)

\section{Directors}

James Carl, Cleveland State University (2005-2007)

Jack Dougherty, Trinity College (2006-2007)

INDIVIDUAL MEMBERSHIP: Membership is open to all persons interested in the study of the history of education. Membership provides for subscription to the History of Education Quarterly; subscription to The Network, a newsletter published jointly with Division F of the American Educational Research Association; and receipt of the program of the annual meeting of the Society. Members of the Society are automatically members of the International Standing Conference for the History of Education. Membership offers subscription to publications on a calendar-year basis only. Dues are $\$ 25$ for students, $\$ 50$ for others. NonU.S. members should add $\$ 7$ to cover additional postage for surface mail; $\$ 20$ for airmail. To become a member, send a check for the appropriate amount in U.S. dollars only to Journal Customer Services, Blackwell Publishing Inc., 350 Main Street, Malden, MA 02148, USA, or to pay by credit card visit www.blackwellpublishing.com/journals/hoeq/members.htm

Make checks payable to Blackwell Publishing. Indicate preferred mailing address and the calendar year in which your subscription should begin. 
History of Education Quarterly, Print ISSN: 0018-2680 Online ISSN: 1748-5959, is published quarterly on behalf of the History of Education Society in conjunction with the College of Education, the University of Illinois at UrbanChampaign, 360 Education Building, MC-708, 1310 South Sixth St, Champaign, IL 61820 by Blackwell Publishing with offices located at 350 Main St, Malden, MA 02148-5020 USA, 9600 Garsington Road, Oxford OX4 2DQ, LK, and PO Box 378, Carlton South, 3053 Victoria Australia.

Article Submissions: Manuscripts must be submitted electronically to the History of Education Quarterly manuscript submission site, http://ojs.ed.uiuc.edu/index.php/heq/index. Questions regarding submissions can be directed to the editorial staff at heq@ed.uiuc.edu. See last page of this issue or our website www.blackwellpublishing.com/HOF.Q for guidelines on submission. The editor will only consider articles that have been submitted exclusively to the History of
Education Quarterly.

Book Reviews: Assignments of reviews are made from a file of potential reviewers. To have your name added to that file. send curriculum vitae to the book review editor. Requests to review particular books cannot be honored.

\section{Subscriber Information}

Journal Customer Services: For ordering information, claims and any inquiry concerning your journal subscription please contact your nearest office:

UK: Email: customerservices@blackwellpublishing.com; 'Tel: +44 (0) 1865778315 ; Fax: +44 (0) 1865471775

USA: Email: customerservices@blackwellpublishing.com; Tel: +1 7813888206 or 18008356770 (Toll free in the LS.A); Fax: +17813888232

Asia: Email: customerservices@blackwellpublishing.com; Tel: +6565118000 ; Fax: $+4+(0) 1865+71775$

New orders, renewals, sample copy requests, claims, change of address information, and all other correspondence should be sent to Journals Customer Service at the publisher's US or LiK office (see addresses above).

Mailing: Periodical postage paid at Boston, MA and additional offices. Mailing to rest of world by DHL Smart \& Global Mail. Canadian mail is sent by Canadian publications mail agreement number 40573520 . Postmaster: Send all address changes to History of Education Quarterly, Blackwell Publishing, 350 Main St., Malden, MA 02148-5020

\section{Subscription Rates (2007):}

A subscription to History of Education Quarterly includes online access to all available electronic volumes.
Annual Subscription Rates (2007)
Institutional Premium Rate*
The Americas
$\$ 126$
Rest of World

*Includes 4 issues of History of Education Quarterly as well as online access to full text articles from 1997 to present, where available.

Customers in the UK should add VATat $6 \%$; customers in the EU should also add VATat $6 \%$, or provide a VAT registration number or evidence of entitlement to exemption. Customers in Canada should add 6\% GST or provide evidence of entitlement to exception. The Premium institutional price includes online access to full text articles from 1997 to present, where available. For other pricing options or more information about online access to Blackwell Publishing journals, including access information and terms and conditions, please visit www.blackwellpublishing.com/HOEQ.

Back Issues: The current and previous year's issues are available from Blackwell Publishing. Earlier Volumes can be obtained from the Periodicals Service Company, 11 Main St. Germantown, NY 12526, USA. Email: PSC@periodicals. com. Tel: (518) 537-4700. Fax: (518) 537-5899

\section{Copyright and Photocopying}

" 2007 History of Education Society. All rights reserved. No part of this publication may be reproduced, stored or transmitted in any form or by any means without the prior permission in writing from the copyright holder. Authorization to photocopy items for internal and personal use is granted by the copvright holder for libraries and other users registered with their local Reproduction Rights Organisation (RRO), e.g. Copyright Clearance Center(CCC), 222 Rosewood Drive, Danvers, MA 01923, USA (www.copyright.com), provided the appropriate fee is paid directly to the RRO. This consent does not extend to other kinds of copying such as copying for general distribution, for advertising or promotional purposes, for creating new collective works or for resale. Special requests should be addressed to Blackwell Publishing at: journalsrights@oxon.blackwellpublishing.com.

\section{Advertising}

For advertising information please visit the journal website at www.blackwellpublishng.com/hoeq or contact the Academic and Science Journal Advertising Sales Coordinator at journalsusa@bos.blackwellpublishing.com, 350 Main St., Malden, MA 02148. Phone: 781-388-8532. Fax: 781-338-8532.

\section{Disclaimer}

The Publisher, History of Education Society, and Editors cannot be held responsible for errors or any consequences arising from the use of information contained in this journal; the views and opinions expressed do not necessarily reflect those of the Publisher, History of Education Society, and Editors, neither does the publication of advertisements constitute any endorsement by the Publisher, History of Education Society, and Editors of the products advertised.

\section{Blackwell Synergy}

Keep up with new publications from Blackwell Publishing. Join our free e-mail alerting service, and we'll send you journal tables of contents (with links to abstracts) and news of our latest books in your field. Signing up is easy.

Simply visit www.blackwellpublishing.com/ealerts.

- Choose which discipline interests you, and we'll send you a message every other week.

- OR select exactly which books and journals you'd like to hear about, and when you'd like to receive your messages. This journal is available online. Contact your librarian or visit www.blackwellsynergy.com. 


\section{History \\ of Education \\ Quarterly}

Volume $46 \bullet$ Number $4 \bullet$ Winter 2006

\section{Contents}

\section{Articles}

487

"We want no teachers who say that there are two sides to every question": Conservative Women and Education in the 1930 s

Cbristine K. Erickson

The Medicalization of Education: A Historiographic Synthesis

Stephen Petrina

Moving Up the Ranks: Chiefly Status, Prestige, and Schooling in Colonial Fiji

Carmen M. White

The Curious Status of the History of Education: A Parallel Perspective

Fobn L. Rury

\section{BOOK REVIEWS}

Bai, Shaping the Ideal Child: Children and Their Primers in Imperial China

By $Y u-W e n$ Cbou

Boger and Orfield, (eds.), School Resegregation: Must the Soutb Turn Back?

By Jayne R. Beilke 

the Modern South

By Phoebe Godfrey

611 Deslandes, Oxbridge Men: British . Masulinity and the Cindergraduate Experience, 1850-1920

By $W$. Bruce Leslie

614 Fraser, A History of Hope: When Americans Har'e Dared to Dream of a Better Future

By Sarah Machiels Bennison

617 Friedman, Masculinity, Autoway, and the Rusiun Liniersit). 1804-1863

By E. Thomas Euing

620 Grinberg, "Teaching Like That," The Beginnings of Teachor

Education at Bank Street

By Kathleen A. Murphey

623 Jackson, Science for Segregation: Race, Law, and the Case Against Brown v. Board of Education

By Joseph Watras

625 Justice, The War that Wasn't: Religious Conflict and Compromice in the Common Schools of New York State, 1865-1900

By Marla A. Bemett

628 Kaiser (ed.), Pedagogy and the Practice of Sicence: Historical and Contemporary Perspectives

By John L.. Rudolph

631 Keller, Transforming a College: The Story of a Little-Known College's Strategic Climb to National Distinction By Michael W. Simpson

Kink and Cahill, Class Wars: The Story of the Washington Education Association 1965-2001

By Daniel Golodner

Lassonde, Learning to Forget: Schooling and Family Life in New Haven's Working Class 1870-1940

By Kelly Ann Kolodny

640 Lawn and Grosvenor (eds.), Materialities of Schooling By Peter Cunningham 
Lefever, Undaunted by the Fight: Spelman College and the Civil Rights Movement, 1957-1967

By Amy Thompson McCandless

Lin, Peking University: Chinese Scholarship and Intellectuals, 1898-1937

By Tbomas D. Curran

Mickenberg, Learning from the Left: Children's Literature, the Cold War, and Radical Politics in the United States By Kennetb Teitelbaum

Nelson, The Elusive Ideal: Equal Opportunity and the Federal Role in Boston's Public Schools, 1950-1985

By Tracy Schuster

Ogren, The American State Normal School: "An Instrument of Great Good"

By Barbara Speas Havira

Osgood, The History of Inclusion in the United States By Stephen Woolworth

Pearcy, The Grammar of Our Civility: Classical Education in America

By Milton Gaither

Pelfrey, A Brief History of the University of California By fobn S. Whitebead

Robbins, Managing Literacy, Mothering America: Women's

Narratives on Reading and Writing in the Nineteenth Century By Barbara Rutb Peltzman

Robertson, Crimes Against Children: Sexual Violence and Legal Culture in New York City: 1880-1960

By Fennifer De Forest

Schissler and Soysal (eds.), The Nation, Europe, and the World: Textbooks and Curricula in Transition

By Lisa L. Zagumny

Schneller, Breaking the Color Barrier: The U.S. Academy's First Black Midsbipmen and the Struggle for Racial Equality By Lee S. Duemer 
676 Street, Segregated Schools: Educational Apartheid in Post-Civil Rights America

By Fayne R. Beilke

679 Trelease, Making North Carolina Literate: The University of North Carolina at Greensboro from Normal School to Metropolitan University

By Fohn D. Adams

Ulrich (ed.), Yards and Gates: Gender in Harvard and Radcliffe History and Rosenberg, Changing the Subject: How the Women of Columbia Shaped the Way We Think about Sex and Policies By Kimberly Marinucci

Vinovskis, The Birth of Head Start: Preschool Education Policies in the Kennedy and Fobnson Administrations

By Barbara Beatty

691 Westhauser, Smith, and Fremlin (eds.), Creating Community: Life and Learning at Montgomery's Black University. By Mary S. Hoffschwelle

Wilkinson, Aiding Students, Buying Students: Financial Aid in America

By Marsha V. Krotseng

Wills, No Ordinary College: A History of the University of Virginia's College at Wise

By Elizabeth P. Harper

Index of Volume 46

PHOTO CREDIT: Susan La Flesche (standing) with her sister Marguerite (right) at the Elizabeth Institute for Young Ladies in Elizabeth, New Jersey, 1879. Susan La Flesche went on to attend Hampton Institute and the Women's Medical College of Pennsylvania and became the first Native American woman to become a licensed physician. Photograph used by permission of the Nebraska State Historical Society. 